NJDRS

CDRD

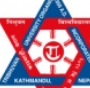

\title{
Vegetable Gardening and Marketing in Kirtipur Area of Kathmandu
}

\author{
Dhyanendra Bahadur Rai \\ Associate Professor, Central Department of Geography, Kirtipur, TU \\ Email for correspondence: dbrrai@yahoo.com
}

\begin{abstract}
Vegetable gardening is one of the important branches of vegetable farming in which vegetables are produced for the purpose of self-consumption and local market. In these days, the demand of fresh vegetable is increasing day by day because of rapid population growth, urbanization and growing awareness towards green vegetable in the kitchen. Hence, in the urban fringes, vegetable gardening has appeared as one of the productive enterprises for cash generation as well as self-employment. This study is completely based on primary data collected in the field by household questionnaire survey, key informants interview as well as focus group discussion (FGD). Finding clearly indicates that the cultivation of vegetable around Kirtipur area is gradually increasing and also able to fulfill few demands of vegetables in the local market of Kirtipur. This area has emerged as one of the vegetable growing pocket area among the outlying areas of Kirtipur Municipality.
\end{abstract}

Key words: Vegetable gardening, Machchhegaun, women participation and marketing channel.

\section{Introduction}

Vegetable gardening is the part of agricultural geography. It comprises of vegetable production in the small piece of land or gardens in limited quantity for home use and marketing purpose as well. Vegetable gardening is synonymously used as market gardening, home gardening and fresh vegetable market gardening where vegetable are basically grown for the fulfillment of urban demand. Generally, the cropping pattern in such gardens depends on the local market demand. Due to high price of land, intensive methods of cultivation are followed and most skillful methods for growing vegetables for commercial purposes are adopted (McCracken \& Revel, 1982). Market gardening is usually applied to intensive type of vegetable farming found in the urban peripheries due to increasing number of unskilled migrants from the rural areas aiming employment and other opportunities in the present days. The demand of vegetable is increasing day by day because of rapid population growth, urbanization and awareness of health that has given birth to an increased demand for fresh fruits and vegetables (Nichols \& Hilmi, 2009). The low consumption of vegetable clearly indicates poor diet and this obviously affects the efficiency of the people. For a balanced diet, the proportion of vegetable needs per capita per meal is considered to be 45 percent of total volume of the foods. This is only true when the vegetable are consumed in a fresh and unprocessed condition (Agusiabo, 1979).

Increased vegetable production may improve food security and offer employment opportunities and additional income for women, young and marginalized communities (Rajbanshi, 1985).Not only this, vegetable gardening can contribute to raising incomes and improving living standards of local people. In the urban fringes, where agriculture is the occupation for livelihood and cash income, vegetable gardening appears as one of the productive enterprises for cash generation (Devkota \& Pradhan, 2006). The trend of commercial vegetable gardening is increasing 
in the recent days rather than for home consumption only as the result of over growing population, increasing demand of vegetable, and awareness of people towards vegetable consumption in their daily diet (Sapkota, 2009). The role of vegetable gardening is important in a country like Nepal where majority of people grow cereal crops (Upadhya, 2006). The cultivation of vegetables around Kirtipur Municipality is gradually increasing where the farmers out of main city area of Kirtipur are engaged for the vegetable production and they are also able to fulfill few demands of vegetables. Growing price of vegetable in the market has also led to kitchen garden. The purpose of farmers is not only for domestic consumption but also earning cash through selling vegetable. Periphery of Kirtipur, especially Machchhegaun emerged as one of the vegetable growing pocket area in Kirtipur Municipality. Machchhegaun is playing important role for supplying to increasing demand of fresh vegetables in Kirtipur bazar area. This study seeks to find out the present condition of vegetable gardening and its marketing channel in Machchhegaun, Kirtipur.

\section{The Study Area}

Kirtipur is an old settlement located on the south west of the Kathmandu valley and it is one of the ten municipalities in the valley. It is located at $27^{0} 38^{\prime} 37^{\prime \prime}$ to $27^{0} 41^{\prime} 36^{\prime \prime}$ north latitude and $85^{\circ} 14^{\prime} 64^{\prime \prime}$ to $85^{\circ} 18^{\prime} 00^{\prime \prime}$ east longitude. It has 10 wards and covers an area of 1787 hectares. It is bordered by the Lalitpur district to the east, Chandragiri Municipality to the west, Dakshinkali Municipality to the south, and Nagarjun Municipality and Kathmandu Metropolitan City (KMC) to the north. The selected site for the study is Machchhegaun which is located at Kirtipur Municipality seven. It is two kilometer far from main city area of Kirtipur. Regular bus service is available from Kathmandu city to Machchhegaun directly. It is also old settlement dominated by Kshetri and Brahmin starting from very beginning after the conquering Kathmandu in the process of integration of Nepal by Prithvi Narayan Shah. Now, it has become as a mixed settlement of different castes and ethnicities.

\section{Methods and Materials}

Machchhegaun is selected for the study site. The reason for the selection of this area is that most of the households are engaged in agriculture as traditional occupation. According to the record of the ward, total households of the study area (ward number 7) are 418. Among the total household, 183 households (43\%) grow vegetable. Therefore, 55 households are selected (30\%) as sample. Simple random method has been applied for this purpose. The study is mainly based on primary data collected from the field. The data are collected during the field survey by applying household questionnaire. Key informant interviews (KII) have been conducted with five farmers; three female and two male. FGD has also been carried out in three groups. The size of the group ranges from five to seven people. Attempts are made to involve people with different castes and ethnicities involving in vegetable gardening. Marketing informations are collected from vegetable shopkeepers in the market, retailers in the footpath and wholesalers.

\section{Findings: Production of Different Crops}

Attempt has been made to determine the area and production of all crops cultivating in this area. Beside vegetable, other crops such as paddy, maize and wheat are grown according to season in Machchhegaun. The covering area is highest with paddy followed by wheat. Maize has the lowest position for covering area. The situation is right opposite about production and productivity. Among all crops vegetable has high yield per unit area and plays a significant role in economy. The area and production of different crops are presented in table number 1. 
Table 1. Area and Production of Different Crops

\begin{tabular}{clccc}
\hline S. $\mathbf{~ N .}$ & Crops & Area in Ropani & Percent & Production in Kg. \\
\hline 1 & Vegetable & 12 & 6.8 & 275,00 \\
2 & Paddy & 65 & 37.1 & 20,000 \\
3 & Maize & 53 & 3.2 & 20,400 \\
4 & Wheat & 45 & 25.7 & 4,800 \\
Total & & $\mathbf{1 7 5}$ & $\mathbf{1 0 0}$ & $\mathbf{7 2 7 0 0}$ \\
\hline
\end{tabular}

(Field Survey, 2016).

The above table shows that the people of Machchhegaun produce different crops in a year. Among the different crops vegetable is first position in term of production. The total production of vegetable is 27,500 kilograms which covers only 12 Ropani of farmed area. The total production of paddy is 20,000 kilograms which covers 65 Ropani of farmed area. Similarly, the total production of maize and wheat are 20,400 and 4,800 kilograms which covers 53 Ropani and 45 Ropani of farmed area.

\section{Annual Income Level of the Farmers}

Vegetable farming is done with two purposes i.e. household consumption and as a source of cash income. It is cultivated in Machchhegaun taking both purposes. Most of the respondents of Machchhegaun grow vegetable for earning cash from their produced vegetable. So, we can say that vegetable is an important source of cash in this area. Being no more profitable from other crops, trend of farmers towards vegetable cultivation is increasing since a decade ago. Farmers of the study area have been cultivating vegetable for 5 to 8 years for selling purpose. Economic status of the farmers has been increasing. Income level of sampled households has been shown in table number 2 .

Table 2. Annual Income Level of the Farmers

\begin{tabular}{cccc}
\hline S. N. & Income Level in NRs. & Number of Households & Percentage \\
\hline 1 & Below 10,000 & 23 & 41.91 \\
2 & $11000-20000$ & 17 & 30.90 \\
3 & $21000-30000$ & 6 & 10.90 \\
4 & $31000-40000$ & 5 & 9.09 \\
5 & 41000 above & 4 & 7.27 \\
& & $\mathbf{5 5}$ & $\mathbf{1 0 0}$ \\
\hline
\end{tabular}

(Field Survey, 2016).

The above table shows that 23 households earn less than 10,000. Similarly, 17 households earn between 11,000 -20,000, 6 households earn 21,000 to 30,000, 5 households are earning from 31,000 to 40,000 and 4 households earn above 41,000 . Households with low income are in more number and high income households are in less number. A large number of household earn below 10000 rupees because they consume their large part of produced vegetable in the household due to big family size. Some of the households who have not major occupation except agriculture grow more vegetables in their garden. So, only 7 percent households earn above 41000 from commercial vegetable farming.

\section{Types of Vegetable Production and Income}

There are various types of vegetable production in the study area, such as cabbage, cauliflower, bean, radish, broad leaf mustard, spinach leaf, cress leaf, squash, pumpkin, skush, garlic etc. Broad leaf mustard, radish and cauliflower are most important and popular winter vegetable. Similarly, pumpkin, squash, and cabbage are more prevalent type of summer vegetable. 
Garlic is the spice type of crop which is grown in the winter season. It has been shown detail in table number 3 .

Table 3. Types of Some Selected Vegetable Production and Income

\begin{tabular}{clccc}
\hline S. N. & Types of Vegetable & \multicolumn{3}{c}{ Vegetable Production in Kg. } \\
\cline { 3 - 5 } & & Production in Kg. & Kg/NRs. & Amount (in NRs.) \\
1 & Cabbage & 6,000 & 30 & $1,80,000$ \\
2 & Cauliflower & 8,000 & 40 & $3,20,000$ \\
3 & Radish & 2,000 & 35 & 70,000 \\
4 & Bean and pea & 1,000 & 30 & 30,000 \\
5 & Broad leaf mustard & 5,500 & 40 & $2,20,000$ \\
6 & Spinach leaf & 2,000 & 45 & 90,000 \\
7 & Cress leaf & 2,000 & 45 & 90,000 \\
& Total & $\mathbf{2 7 , 5 0 0}$ & & $\mathbf{1 0 , 0 0 , 0 0 0}$ \\
\hline
\end{tabular}

(Field Survey, 2016).

The above table indicates that total production of vegetable is $27500 \mathrm{~kg}$. in the sample households which earns 1 million Rs. in a year. The cauliflower ranks in first position for production and income earning followed by broad leaf mustard and cabbage. The price fluctuates round a year. So, average price has been derived. Cabbage and bean has low price and spinach and cress leaf has high price. And the highest price belongs to spinach and cress leaf.

\section{Types of Manure Used While Farming}

There are mainly three types of manure as practice in the study area such as compost, chemical and both are used for vegetable production. Cow dung is the main source of compost manure in Machchhegaun. However, the main purpose of keeping cow is for milk. Most of the Kshetri-Brahmins communities resided in Machchhegaun keep one cow and some goat in their shed. Goat is reared for meat purpose and cash income. Gradually, the trend of keeping cow is decreasing because of shortage of manpower and grazing land. Increasing trend of chemical fertilizer has also replaced the uses of compost manure in this area (see in table number 4).

Table 4. Types of Manure Using by Vegetable Growers

\begin{tabular}{clcc}
\hline S. N. & Types of Manure & Number of Households & Manure (in Kg) \\
\hline 1 & Compost & 8 & 3,400 \\
2 & Chemical & 7 & 60 \\
3 & Both & 40 & 4,000 \\
Total & & $\mathbf{5 5}$ & $\mathbf{7 , 4 6 0}$ \\
\hline
\end{tabular}

(Field Survey, 2016).

The above table shows that farmers use compost and chemical fertilizer among them both users are the highest in Machchhegaun. In Machchhegaun, compost users seem to be higher than chemical. A study about peri-urban agriculture in Kathmandu Valley, done by Sapkota (2009) also draws to similar types of conclusion. Most of the vegetable growers think that the use of single chemical fertilizer harms for the soil fertility. So, they use mixed method for manure. However, farmers use too much pesticides and it would be economically beneficial for them to reduce the amount they use. Chemical pesticides play an important role in vegetables by combating pests. It has negative impact on human health and the environment and also it affects soil also.

\section{Participation of Women in Vegetable Gardening}

In many developing countries, women/children primarily are involving in vegetable production. In Nepal, mostly women are still engage in household chores. Additional time from kitchen they can provide for vegetable gardening. Majority of the women are engaged in this way. 
Vegetable is considered as the essential materials for running kitchen. Women are always associated with vegetable due to their daily responsibility of preparing food. Hence, participation of women in vegetable production is essential. This will allow women to be more self-sufficient, independent, increase their capabilities and improve their social status in their families and communities. Women role is important for different activities of vegetable farming; plantation, weeding, collecting and selling (see in table number 5).

Table 5. Participation of Women in Vegetable Gardening

\begin{tabular}{clcccc}
\hline S. N. & Works & Male & Percent & Female & Percent \\
\hline 1 & Land preparation & 63 & 58.3 & 160 & 29.4 \\
2 & Plantation & 25 & 23.1 & 140 & 25.7 \\
3 & Weeding & 15 & 13.9 & 90 & 16.5 \\
4 & Collection & 5 & 4.6 & 55 & 10.1 \\
5 & Transportation & - & - & 100 & 18.3 \\
Total & & $\mathbf{1 0 8}$ & $\mathbf{1 0 0}$ & $\mathbf{5 4 5}$ & $\mathbf{1 0 0}$ \\
\hline
\end{tabular}

(Field Survey, 2016).

The above table shows that women participation holds 25.7 percent on plantation, 16.5 percent on weeding, 10.5 percent on collection and 18.3 percent on transportation. Participation of men for especially on land preparation is more than women, because it needs more physical hard works. Unemployment, easy source of income, easy to work, suited farming for women are major causes of women participation in vegetable cultivation in this area. As reported by key informants, role of women in the community has been increased after starting vegetable cultivation and they are economically independent to some extent. Life standard of women has been improved by vegetable cultivation.

\section{Role of Women in Decision Making}

Vegetable farming has become a kind of entrepreneurship in Machchhegaun. This has helped to uplift income level of women by cash earning from vegetable gardening. The empowerment of women has also increased along with economic rising of them. It has led to the women in strong position for self-decision. In this point, it has shown that the role of women in decision making process for domestic works and others before and after vegetable cultivation (see in table number 6).

Table 6. Role of Women in Decision Making

\begin{tabular}{lcccc}
\hline Duration & Wife & Husband & Both \\
\hline Before & & 8 & 10 & 36 \\
After & 18 & 0 & 38 \\
Total & $\mathbf{2 6}$ & $\mathbf{1 0}$ & $\mathbf{1 0 8}$ \\
\hline
\end{tabular}

(Field Survey, 2016).

The above table shows that, women of 8 households decide themselves and 36 households decide both before vegetable cultivation. At present women of 18 households decide themselves and 38 households involved both in decision making. Men of 10 households decide himself before vegetable cultivation, at present no one decides. The table shows women role is more than men because of men are job holder and all house activities are under women. 


\section{Marketing Channels in Machchhegaun, Kirtipur}

Marketing channel depends upon characteristics of products and distance of markets (Aryal, 1992). The perishable agricultural products especially leafy vegetables and fruits have shorter channel compared to storable commodities. Accordingly marketing costs and profit margins also vary because fruits and vegetables are perishable, and have a high incidence of damage especially during transport. Thus, if the degree of freshness diminishes, so does the price of the commodity, low return and high marketing costs (Pradhan \& Subedi, 1985). Vegetable growers must have a marketing strategy. The key strategy issue to be addressed is that vegetables, once harvested, will deteriorate and eventually perish. As a result, growers need to plan a balance between the quantity of vegetable available for sale, the variety of vegetables for sale, the location of their particular vegetables in the consumer market and the marketing channel through which the produce will be marketed to consumers (Sharma, 1983). Market gardeners must also determine which of the following channels or combination of channels provide the best means for marketing their produce to consumers. In this regard, marketing channel may be considered as a connecting link. Or, it is bridging between specialized producers (farmers) and consumers through market. So, market and marketing channel is the complementary part of each other. For the commercial vegetable production, marketing channel is another essential factor.

Vegetable growers of Machchhegaun sell their vegetable to Kirtipur, Nayabazar, which is situated at $2 \mathrm{~km}$ distance. Most of the vegetables are transported on back by on foot. As suggested by the members of FGD and KII, the vegetable, produced by farmers in Machchhegaun is supplied to consumers by two methods i.e. direct and non-direct. While vegetables are sold directly to consumers from farmers is called direct channel. About 30 percent of the total vegetable produced by them in Machchhegaun is sold from this channel. Vegetable growers are more active in this regard. Basically, women producers are engaged in this activity. The direct channel is also completed into three ways such as home gate, on the way and foot path in Kirtipur (see fig. 1). In the first way, vegetable is sold in the home garden by farmer themselves. It occupies 10 percent. The consumers (local people and residential) go to buy fresh vegetables to the producers in the field. There is found fresh vegetable a little cheap rate than in the market. The vegetable growers sell vegetable in the foot path of Kirtipur, Nayabazar by carrying as heavy load in the bamboo basket and sometimes in the bus. This process occupies 20 percent of transaction in the total. Some of the vegetable is sold on the way walking from Machchhegaun to Kirtipur. There is no appearance of wholesale and retail traders.

Figure 1: Market channel of vegetable producer in Machchhegaun, Kirtipur

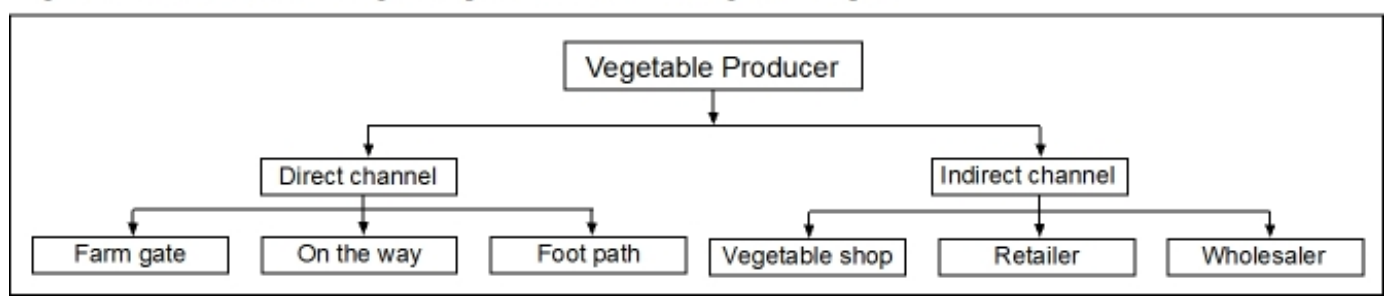

Rest of the vegetable (70 percent) of Machchhegaun is consumed by non-direct method. This method is accomplished through shopkeeper, retailers, and wholesaler (see figure 1). The second method is also completed into three steps. Some producer brings themselves to local 
vegetable shops located in Bhatkepati and Kirtipur, Nayabazar. They give in wholesale price and shopkeeper sell again taking some profit. In the total, about 20 percent vegetable is consumed by this way. Similarly, about 30 percent vegetable is purchased by retail traders through vegetable growers. They take vegetable in wholesale price in the field and take to market especially in Kirtipur and they resell by taking some profit. Another channel of vegetable marketing is wholesale. This occupies about 20 percent transaction in the total. The wholesaler purchases vegetable in the field and brings to Kalimati and Balkhu Tarkari bazar. Most of the vegetable produced in Machchhegaun (40\%) is sold especially in the evening in the open space nearby road in Kirtipur putting in the bamboo basket and plastic mat. So, in the rainy season, the problem of marketing becomes serious. About, 80 percent vegetable is supplied in the local market Machchhegaun, Bhatkepati and Kirtipur, Nayabazar and rest 20 percent in other areas.

\section{Conclusion}

The vegetable gardening is popular in the periphery of urban areas in the country, and it could fulfill the growing demand of population by regular supply of fresh vegetable in the urban center of the market. It could directly support the income generation through better use of unemployed or semi-employed manpower in the rural areas mainly involved in agriculture occupation. It was observed that the vegetable gardening is one of the income sources and it was started from a decade ago in Machchhegaun. Machchhegaun is playing important role in meeting the some part of increasing demand of fresh vegetables in Kirtipur bazar area. After involving in vegetable gardening, women have been empowered in this place. Really, women are more benefitted from vegetable gardening. There has been observed two kinds of market channel in Machchhegaun. The first is direct supply from producer to bazar and the second channel consists of local shopkeeper, retailer and wholesaler. Vegetable growers cannot achieve more benefit from vegetable gardening when it takes long marketing channel. For taking more profit, cooperative marketing system is favorable. If it is so, the vegetable farming will be done successfully. As a result, it helps to raise economic condition especially of women and reduce unemployment problem to some extent in this area. Management of systematic vegetable market is necessary in Kirtipur that enhances favorable condition for vegetable gardening in Machchhegaun.

\section{References}

Agusiabo, O. N. (1979). Vegetable Gardening. London: Million Education Ltd.

Aryal, A. (1992). Vegetable Marketing in Kathmandu Valley, [Unpublished MA Thesis]. Submitted to Central Department of Economics, TU, Kirtipur, Kathmandu, Nepal.

Devkota, F. R. \& Pradhan, P. K. (2006). Urban Agriculture in Tokha, Kathmandu: Potentials for Urban Food Security and Employment. Agricultural Development Journal. MoA, Department of Agriculture, Directorate of Agriculture Training, Lalitpur.

McCracken, C. \& Revel, R. D. (1982). Domestic and Commercial Vegetable Gardening in Dawson City. ARTIC, 35 (3), 395-402.

Nichols, M. \& Hilmi, M. (2009). Growing Vegetables for Home and Market. Rural Infrastructure and Agro-Industries Division. Food and Agriculture Organization of the United Nations, Rome. 
Pradhan, P. K. \& Subedi, B. P. (1985). A Study of Fresh Vegetable Market in Kathmandu City. A Project Report Submitted to Institute of Humanities and Social Science, TU, Kirtipur, Nepal.

Rajbanshi, A. S. (1985). Vegetable Gardening in Kathmandu City: A Case Study of Ward no. 16, [Unpublished MA Thesis]. Submitted to Central Department of Geography, TU, Kirtipur, Nepal.

Sapkota, K. (2009). Farmer's Choice and Farmer's Voice on the Use of Local Versus Modern Inputs in Peri-urban Agriculture in Kathmandu Valley, Nepal. The Geographical Journal of Nepal, 7, 15-22.

Sharma, Y. P. (1983). Vegetable Marketing Practices in Nepal with Reference to Pokhara Town, Discussion Paper, Eco. Ins. Committee, P. N. Campus, Pokhara. 